DOI https://doi.org/10.30525/978-9934-588-90-7-54

\title{
THEORETICAL AND APPLIED ASPECTS OF COMBINATORICS
}

\author{
Tsapenko L. E. \\ Candidate of Philological Sciences, PhD, \\ Associate Professor at the Foreign Languages Department \\ Odesa National Polytechnic University \\ Odesa, Ukraine \\ Lebedeva $\mathbf{O}$. V. \\ Senior Lecturer at the Foreign Languages Department \\ Odesa National Polytechnic University \\ Odesa, Ukraine \\ Gvozd O. V. \\ Senior Lecturer at the Foreign Languages Department \\ Odesa National Polytechnic University \\ Odesa, Ukraine
}

Combinatorics, i.e. combination of linguistic elements, got its start in linguistics in the 50-s of the last century on the basis of the study of the syntactic verb potentials when L. Tenier [3] in the process of the structural analysis of the sentence within the framework of his grammar of dependencies began to proceed from the ability of the verb to accept and keep a certain number of "actants". L. Tenier compared this ability of the verb with wellknown property of atom in chemistry and called it "valence" [3]. Thus, the concept of valence and the corresponding term has appeared in linguistics.

Initially L. Tenier and then a number of other German linguists considered valence exclusively as a property of a particular part of speech to have "participants" with it i.e. they focused exclusively on functional and semantic features [1;2; 4]. However, J. Erben [5] guided by the principle of semantic obligation of dependent members identified the basic structural models of a simple sentence in German, and no longer limited the scope of valence bonds with immediately adjacent syntactic units but extends it to almost all components of the sentence.

Trying to clarify the concept of valence the researchers drew attention to its qualitative characteristics since each part of speech has the property of selectivity in relation to the elements dependent on it and is combined in accordance with this property not with any members of the sentence but those that are within the sphere of its influence [6]. 
This attempt to take into account the selection valence properties of parts of speech G. Helbig implemented in compiling the "Dictionary of valence and distribution of German verbs" which gives a brief qualitative description of the obligatory verb connections [2]. Thus the theoretical concept of syntactic valence has found a way out in practice when using the phenomenon of valence for the needs of lexicography and language teaching.

Nevertheless a number of issues remained unresolved. These include such a question as the volume of the environment of one or another part of speech in a sentence, determined by the valence. Therefore the problem of combinatorics or, according to the terminology of French and German linguists $[1 ; 2 ; 3 ; 4]$ - valence, needed to be developed from the standpoint of dichotomy i.e differentiation of language and speech. This provision defines a new approach to the study of the combinatorics of linguistic units. It allowed the researchers to single out the linguistic and speech aspects of combinatorics and consider them separately which contributes to a deeper understanding of interaction of the mentioned aspects of combinatorics that exist in unity.

In numerous studies in which the authors, describing the combinatorics of units of various linguistic levels or the features of combinatorics in only one aspect, distinguished its (combinatorics) following types: semantic, lexical (within which, in turn, phraseological and stylistic are distinguished), syntactic, morphological, compatibility of phonemes and even kinakems primary phonological units.

For example, stylistic compatibility reveals the possibilities and conditions for the emergence of new or additional shades of the meaning of a word depending on the speech situation. Semantic compatibility determines the conditions for the semantic agreement / inconsistency of words, their semantic selectivity [5]. In addition, depending on the belonging of units to certain lexical-grammatical classes of words, the compatibility of verbs, adjectives, adverbs, etc. is distinguished.

The basic characteristic of combinatorics of linguistic units is the totality of their connections. So a word as a lexical-grammatical unit can enter into lexical-semantic and grammatical connections with other words forming a certain set of grammatical and lexical connections. The analysis of combinatorics in the lexical sense (lexical compatibility) is traditionally carried out taking into account the lexical-semantic connections of words which (connections) depend on the lexical meanings of these words.

The question of the environmental volume of one or another part of speech in a sentence is closely related to the problem of constructing a model of valence for which it is necessary to know which words can be included in it and which must be omitted i.e. we are talking about the mandatory and 
optional elements of the valence model. Therefore further research in terms of combinatorics is supposed to be devoted to the theoretical analysis of one of its main characteristics - the grammatical connections of words in a sentence which form a certain set of models.

\section{References:}

1. Brinkman H. Die deutsche Sprache „Gestalt und Leistung“. Dusseldorf. 1962. $654 \mathrm{~S}$.

2. Helbig G. Untersuchungen zur Valenz und Distribution deutscher Verben. Deutch als Fremdsprache. Leipzig: Herausgeber Herder-Instutite. 1966. S. I - II. № 3.

3. Tesniere L. Ele, ents de syntaxe structurale. Paris: Fref. de Jean Fourauet, 1959. 670.

4. Weisgerber L. Von den Kräften der deutschen Sprache. Die sprachliche Gestaltung der Welt. Dusseldorf. 1962. 431 S.

5. Erben J. Abriss der deutschen Grammatik. Berlin: Akad. Verl. 1958. $208 \mathrm{~S}$.

6. Салижанов С. К. К вопросу о сочетаемости согласных фонем и слогообразующей роли сонантов. Романо-германская филология и сопоставительное изучение языков. Самарканд. 1979. С. 89-99. 